\title{
Chemical Composition and Antigenic Structure of Cell Walls of Corynebacterium, Mycobacterium, Nocardia, Actinomyces and Arthrobacter
}

\author{
By C. S. CUMMINS \\ Department of Bacteriology, The London Hospital Medical College, London, E. 1
}

(Received 1 June 1961)

\begin{abstract}
SUMMARY
A comparison has been made between the chemical composition of the cell walls of strains from the genera Corynebacterium, Mycobacterium, Nocardia, Actinomyces and Arthrobacter, and the antigenic composition of the same cell-wall fractions as judged by an agglutination test. A common antigenic component was identified in all those strains of corynebacteria, mycobacteria and nocardias which have arabinose and galactose as their principal cell-wall sugars. Some strains of corynebacteria, and 3 strains of Nocardia pelletieri which have a different pattern of cell-wall components, appear to lack this cell-wall antigen. The antigen was not present in the cell walls of 8 strains of actinomyces and 6 of arthrobacter. Seven of the 8 strains of actinomyces had a cell-wall composition identical with that previously described for Actinomyces israelii, and these 7 strains formed a homogeneous group serologically: the other actinomyces strain differed in cell-wall wall composition and its cell walls did not agglutinate with the 'israelii' serum, nor did those of any of the 6 strains of arthrobacter, although some of the latter resemble $A$. israelii in cell-wall structure. These results show that the antigenic studies tended to confirm relationships suggested by cell-wall composition alone, especially among corynebacteria, nocardias and mycobacteria: they also suggest that Corynebacterium as at present constituted is a mixture of species of diverse origin.
\end{abstract}

\section{INTRODUC'TION}

In a previous paper (Cummins \& Harris, 1958) the results were reported of an examination of the cell-wall composition in over 50 strains of actinomyces and related organisms. One of the most striking findings was that the mycobacteria, corynebacteria and nocardias appeared to have identical cell-wall compositions, at least in terms of the principal compounds which could be identified on twodimensional chromatograms, and it was suggested that these three groups must be closely related taxonomically. In earlier work in which cell walls were used as antigens in agglutination tests, Cummins (1954) was able to identify group and specific antigens in the walls of a strain of Corynebacterium diphtheriae type mitis. The group antigen concerned was found in 7 other strains of $C$. diphtheriae (including both gravis and intermedius types) and in a strain of $C$. ovis, but was apparently not present in C.xerosis, C. hofmannii or C. renale. In view of the almost identical pattern of cell-wall components found in corynebacteria, mycobacteria and nocardias, it seemed possible that an immunological study of cell-wall fractions 
from these organisms would be of interest. Preliminary tests showed that there was considerable cross-agglutination when a serum prepared against Mycobacterium smegmatis was tested against cell-wall suspensions from $C$. diphtheriae and Nocardia asteroides. A more extensive investigation was then undertaken, whose results are reported in the present paper. Although there are gaps in the pattern (because not all the cell-wall suspensions could be tested against all the sera) the results seem to show clearly the presence of a cell-wall antigen common to all organisms which have arabinose and galactose as their principal cell-wall sugars. This antigen, however, appears not to be present in the walls of those organisms examined which do not have this pattern of sugar components.

Although some of the cell-wall analyses have been reported in previous papers (Cummins \& Harris, 1956a, 1958, 1959b) they are reproduced again here where appropriate in order to show the correspondence between the over-all pattern of cell-wall components and the presence or absence of the antigen in question. The results of cell-wall analyses and serological tests on a smaller number of strains of Arthrobacter and microaerophilic Actinomyces have also been included.

\section{METHODS}

Origin and naming of strains. Strains obtained from one of the culture collections have the strain number with the appropriate initials, i.e. NCTC (National Collection of Type Cultures), NCIB (National Collection of Industrial Bacteria), NCPP(National Collection of PlantPathogenic Bacteria) or ATCC(American Type Culture Collection). Of the strains from the ATCC, that described in this paper as Corynebacterium simplex ATCC 8373 is no longer kept as such in the collection. (Personal communication from the Curator, Dr F. A. Weiss.) The source of all other strains is given in Table 1. Most of these were obtained as living or freeze-dried cultures, but in the case of the 6 strains of Arthrobacter, and in a few other cases (indicated in Table 1) material was received as dried bacterial suspensions. The names used throughout are those which the strains bore when received.

Preparation of cell-wall fractions. This was done as previously described (Cummins \& Harris, 1956a 1958) by mechanical disintegration in a Mickle tissue disintegrator (Mickle, 1948) with small glass beads, followed by enzyme digestion of the crude cell-wall fraction. The method was however modified slightly in that Liq. Tryp. Co. (Allen and Hanbury) in a final concentration of $1 / 200$ in phosphate buffer (pH 8.0) was used in place of crystalline trypsin, and ribonuclease was omitted from the digestion mixture. Only a very occasional cell-wall hydrolysate showed any trace of ribose when prepared in this way, and there has been no increase in the number so contaminated since the use of ribonuclease was discontinued.

Chromatographic techniques. The method of hydrolysis of cell-wall fractions, and the chromatography of the hydrolysates, were as previously described (Cummins \& Harris, 1956 a), except that, for amino acids, hydrolysis in $6 \mathrm{~N}-\mathrm{HCl}$ was continued for 18-20 hr. at $105^{\circ}$, instead of $8 \mathrm{hr}$. at $100^{\circ}$ as used in earlier work.

Extraction with alkaline ethanol. This was done as previously described with $0.5 \% \mathrm{KOH}$ in ethanol for $48 \mathrm{hr}$. at $37^{\circ}$ (Cummins \& Harris, 1958).

Cultural methods and preparation of bacterial suspension. The mycobacteria, corynebacteria, nocardias and actinomyces were grown as described in previous communications (Cummins \& Harris, 1956a, 1958). The plant pathogens Coryne- 
Table 1. Origin of strains other than those from NCTC, NCIB, NCPP or ATCC

Strain

Mycobacterium M. tuberculosis BCG

M. tuberculosis Human type, strain C

M. rhodochrous

M. cinnabareus $\}$

Corynebacterium

C. diphtheriae 2764 (mitis)

C. diphtheriae XY (gravis)

C. hofmannii L.H.

C. pyogenes Wye 1

C. pyogenes Wye 2

C. pyogenes Wye 3

Nocardia

N. asteroides 3655

$N$. asteroides 6846

N. asteroides 398

N. asteroides $\mathbf{4 4 3}$

N. brasiliensis 536

N. pelletieri 513

N. pelletieri 514

N. pelletieri 778

N. coelica 3520

Nocardia sp. 1083

Nocardia sp. 416

Nocardia sp. 622

Nocardia sp. 736 B

Actinomyces

A. bovis 'Bousseau'

A. bovis $854 \mathrm{~A}$

A. bovis $86 \mathrm{H}$

A. israelii $\mathbf{H} 2$

Actinobacterium

Actinobacterium israelii $1200 \mathrm{~A}$ )

Actinobacterium israelii $\mathrm{B} 1$
Origin

Received as dried, delipidated organisms from

Dr E. Lederer (Paris)

Received as formalin-killed organisms from

Dr A. B. Paterson (Weybridge, England)

London Hospital stock strains

From Dr Donald Payne (Public Health Laboratory, Northallerton, England)

Stock strain of Bact. Dept. London Hospital

From the Veterinary Investigation Centre, Wye, Kent

13 nocardias received from Dr Ruth Gordon, Rutger's University, New Jersey, U.S.A.

Strains of human origin received from Professor Prevot (Paris)

Isolated from case of human actinomycosis

Strains of human origin received from Professor Prevot (Paris)

bacterium fascians, C. betae, C. tritici, C. insidiosum, C. poinsettiae and C. flaccumfaciens were grown on $1 \%(\mathrm{w} / \mathrm{v})$ glucose nutrient agar at $30^{\circ}$.

Organisms grown in liquid medium were killed by the addition of formalin $(40 \%, w / v$ formaldehyde) to a final concentration of $1 \%(v / v$ formalin). Those organisms grown on solid media were washed off in $1 \%$ formol saline (i.e. $1 \%$ formalin in $0.9 \% \mathrm{NaC}$.). In either case, after allowing formaldehyde to act at room temperature $\left(18-22^{\circ}\right)$ for $\mathbf{2 4} \mathrm{hr}$. the suspensions were centrifuged and washed twice in distilled water. When not disintegrated at once they were preserved at $4^{\circ}$ in distilled water containing $0 \cdot 3 \%(\mathrm{w} / \mathrm{v})$ sodium azide.

In a few cases (see Table 1) dried bacterial suspensions were kindly provided by other workers. The freeze-dried materials easily redispersed to give smooth suspensions, but the dried delipidated mycobacteria required to be soaked in saline $(0.85 \%, w / v, ~ N a C l$ solution) overnight, and ground in a Ten Broeck tube to give a suspension which could be disintegrated easily in the Mickle shaker. 
Preparation of antisera. The antisera used in the investigation were produced by immunizing rabbits. Older sera (dated 1952, 1953 and 1954) were prepared as described in a previous paper ( $\mathrm{C}$ Ammins, 1954) by giving an intraperitoneal dose of material as a depot in calcium alginate (Slavin, 1950) followed a few weeks later by intravenous injections. Later sera (dated 1959 and 1960) were prepared by giving twice-weekly intravenous injections, until test bleedings showed a satisfactory response. These animals wt re then bled one week later, and the sera separated and preserved with sodium azide (final concentration about $0 \cdot 3 \%, w / v)$. Sera were stored in the refrigerator at $4^{\circ}$.

The material used to immunize abbits varied from suspensions of intact bacteria to purified cell-wall fractions which had been treated with trypsin and pepsin. In some cases the animals were injected with a partial disintegrate consisting of a mixture of intact bacteria, cell-wall fragments and cytoplasmic constituents produced by a relatively short period of shaking in the Mickle disintegrator. These partial disintegrates were not treated with proteolytic enzymes.

The materials used to prepare ach of the seven sera used in the investigation are detailed in Table 2 together w th a list of the abbreviations by which the sera are referred to in other tables.

\section{Table 2}

Serum against

Mycobacterium smegmatis NCTC 8159 Corynebacterium ovis NCTC 3450

C. diphtheriae type gravis XY

C. diphtheriae type mitis 2764

C. diphtheriae type mitis 2764 Actinomyces israelii

C. pyogenes NCTC 5224

\begin{tabular}{|c|c|c|}
\hline Date & $\begin{array}{l}\text { Abbreviated } \\
\text { title }\end{array}$ & Material injected \\
\hline 1959 & SMEG & Partial disintegrate \\
\hline 1954 & OVIS & Cell walls, trypsin treated \\
\hline 1952 & $\mathbf{X Y}$ & $\begin{array}{l}\text { Intact bacteria, formalin } \\
\text { killed }\end{array}$ \\
\hline 1953 & $2764(\mathrm{~A})$ & $\begin{array}{l}\text { Cell walls, treated trypsin } \\
\text { and pepsin }\end{array}$ \\
\hline 1960 & $2764(\mathrm{~B})$ & Partial disintegrate \\
\hline 1960 & ISR & $\begin{array}{l}\text { Intact organisms, formalin } \\
\text { killed }\end{array}$ \\
\hline 1953 & PYO & Partial distintegrate \\
\hline
\end{tabular}

The principal reason for the apparently random choice of material used to immunize is that not many rabbits responded satisfactorily to any of the preparations used. At one time or another all the materials mentioned have produced antisera which would agglutinate the purified cell walls of the organisms concerned, but in many cases the response has been very poor, and the sera used represent the best of a rather bad lot. It seerned particularly difficult to produce good sera to cell walls of mycobacteria and rocardias, and most of the rabbits responded poorly if at all. In general the most: satisfactory response appeared to follow the injection of a partial disintegrate, given two or three times a week by intravenous injection of rather large amounts (i.t. 5-10 mg.).

Agglutination tests. These were done as described by Cummins (1954) except that the tests were incubated at $56^{\circ}$ for $\mathrm{zhr}$. instead of $1 \mathrm{hr}$. as previously, and were then allowed to stand on the bench for several hours (usually overnight) before the results were read. The longer period of incubation, followed by standing at room temperature, made the tests rather nore sensitive. The results were recorded as ,,,++++++ \pm , tr or negative $(-),+$ indicating the smallest particles easily visible to the naked eye, and tr (trace) indicating particles visible with certainty 
only by using a hand lens $(\times 4)$. With strong reactions the agglutinated material frequently formed a single floccular mass. Where only titres are given (as in Tables $3-5)$ the figure is the reciprocal of the highest serum dilution at which a + or ++ degree of agglutination was found.

Absorption of sera. This was done by suspending $250 \mathrm{mg}$ (wet weight, after draining tube) of the cell-wall suspension in $3 \mathrm{ml}$. of serum diluted $1 / 10$ and incubating at $37^{\circ}$ for $\mathrm{I} \mathrm{hr}$. with occasional agitation. Following this, the mixture was generally placed in the refrigerator at $4^{\circ}$ overnight before the serum was recovered by centrifugation; this final overnight absorption was sometimes omitted. To conserve materials, titrations with absorbed sera were usually started at 1/40 (final dilution) instead of $1 / 20$.

\section{RESULTS}

Extraction with alkaline ethanol. In order to prepare stable cell-wall suspensions for use in the present investigation, it was necessary to use alkaline ethanol extraction with all the mycobacteria and nocardias, and some corynebacteria (e.g. Corynebacterium fascians). Extractions can be performed either on the intact suspension before disintegration and digestion with proteolytic enzyme, or on the cell-wall fraction after enzyme treatment. It is generally more convenient to extract the intact bacteria, as the material is then easier to work with, and none is lost on the walls of tubes or pipettes. It is possible to prepare cell-wall suspensions suitable for agglutination from many corynebacteria without alkaline ethanol extraction (see Cummins, 1954). With organisms other than mycobacteria, corynebacteria and nocardias, extraction was not necessary to prepare antigens, since these strains gave cell-wall suspensions which were stable, or could easily be redispersed by a short treatment in the Mickle disintegrator.

It was obviously important to establish as far as possible that extraction with alkaline ethanol did not destroy antigens which might give rise to agglutination. This was investigated by comparing extracted and unextracted cell-wall suspensions from several corynebacteria where the extraction procedure was not necessary to give reasonably stable antigens. The strains chosen were three strains of Corynebacterium pyogenes (Wye 1, Wye 2, Wye 3), C. ulcerans NCTC 7910, C. xerosis NCTC 9755, C. renale NCTC 7448, C. equi NCTC 1621 and C. ovis NCTC 3450 and the experiment was done by extracting a sample of already prepared cell walls, and testing this in parallel with an unextracted sample against a suitable serum. In the case of the three $C$. pyogenes strains there was no difference in titre between the extracted and unextracted antigens, when tested against serum PYO. In the case of the other corynebacteria, which were tested against serum SMEG, the extracted antigens gave, in general, slightly lower titres, e.g. a decrease from ++ at $1 / 320$ to + at $1 / 160$. However, the unextracted antigens tended to be slightly unstable in saline, whereas the extracted antigens were not. It was concluded that this degree of diminution in titre was unlikely to give false negative results, even supposing it to be due to some destruction of the antigen concerned. Although not absolutely necessary in all cases, therefore, alkaline ethanol extraction was used to prepare cell-wall antigens from all the mycobacteria and nocardias, and from those corynebacteria which have the arabinose + galactose pattern of cell-wall sugars. It was not used for the other corynebacteria listed in Table 3, nor for the other organisms investigated. 
The results of chemical analys s of cell walls are given in Table 3,4 and 5 , together with the agglutination reaction; of the cell-wall suspensions when tested against unabsorbed sera. The results of agglutination tests with absorbed sera are given in Table 6. These serological res alts are discussed later.

Cell-wall composition. The us of cell-wall composition in the classification of actinomyces has been discussed n a previous paper (Cummins \& Harris, 1958) and one of the points made there concerned the identical pattern of cell-wall components found in almost all strains of corynebacteria, nocardias and mycobacteria examined. The present work extends this observation somewhat since it includes results for 29 new strains belonging to these three groups. Some of these 29 strains are of species from which representatives have previously been examined, but others have not been investigated before. For example, no plant pathogenic corynebacteria were included in earlier work, whereas this group is represented here by 6 species: Corynebacterium fascians (3 strains), C. tritici, C. betae, C. poinsettiae, C. insidiosum and $C$. flaccumfaciens. Furthern ore, only one strain of Nocardia asteroides was examined previously and none $\mathrm{o} N$. brasiliensis, $N$. pelletieri or $N$. coelica, all of which are represented in Table 4 . There are also 4 nocardias whose species identification is uncertain, and 4 strains of mycobacteria not previously reported (one strain of $M$ ycobacterium tuberculosis avian type, $M$. phlei, $M$. rhodochrous, $M$. cinnabareus). The cell-wall compositions of thes: 29 mycobacteria, corynebacteria and nocardias in general confirm the earlier findings. It is again apparent that a pattern of cell-wall components consisting of arabinose, galactose, alanine, glutamic acid and DLdiaminopimelic acid is very characteristic of most of the members of these three groups. This is so, for example, in 10 out of the 13 nocardias and in the 4 newly tested strains of mycobacteria. The three strains of $N$. pelletieri, however, differed quite sharply from the other nocar lias. Their cell walls do not contain arabinose or galactose (except for possibly a tre ce of the latter sugar in N. pelletieri 513) while hydrolysates of all of them showed a distinct spot for glycine, and a mixture of LLand DL-diaminopimelic acid. This jattern of major components, with a moderate amount of glycine and a mixture 0 the LL- and DL-isomers of diaminopimelic acid has been noted before in Micromonospora spp. (Cummins \& Harris, 1958) and would appear to be a variant of the patt rn found in Streptomyces spp. where there is a larger amount of glycine and only LL-diaminopimelic acid. These results with $N$. pelletieri suggest that it may be more closely related to Streptomyces than to organisms of the type of $N$. asteroiaes.

Other interesting discrepancies (an also be seen in Table 3. The anomalous position of Corynebacterium pyogen's when compared with other corynebacteria has already been noted (Cummins \& Harris, 1956a), and it now appears that, except for $C$. fascians, the plant pathogenic corynebacteria form another anomalous group. The single strain of $C$. betae stems to be very like the strain of C. poinsettiae; both have rhamnose as a cell-wall ;ugar, and alanine, glutamic acid, lysine and glycine as principal amino acids, a combination of sugars and amino acids which has not been noted before. These four amino acids (alanine, glutamic acid, glycine, and lysine) are characteristic of staphylococci and micrococci, but are not there found with rhamnose. The strain of $C$. flaccumfaciens var. auranticum, in whose walls rhamnose was not detected, has in fact the pattern of major wall components which has so far been regarded as characteristic of most members of the staphy- 


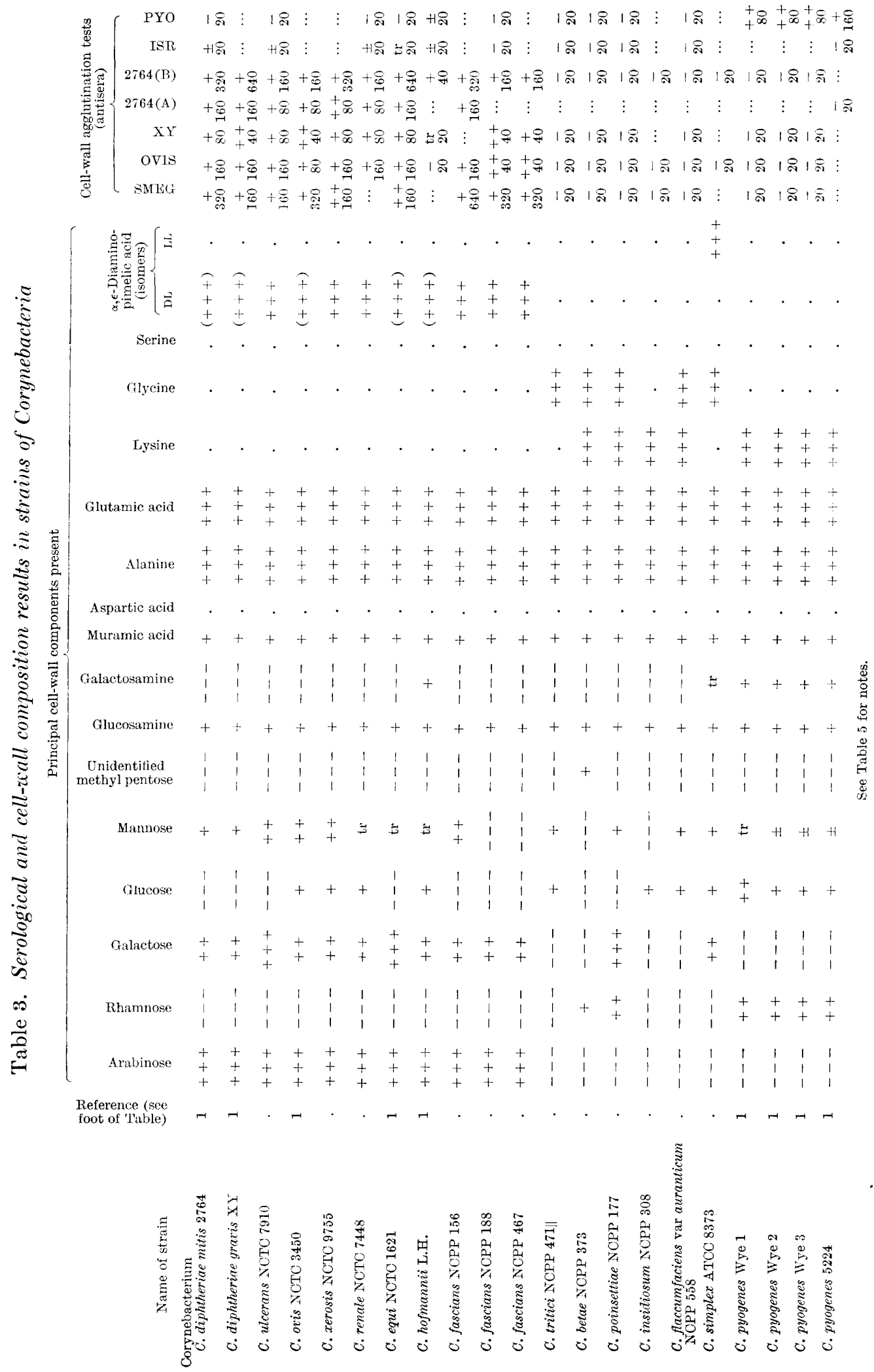




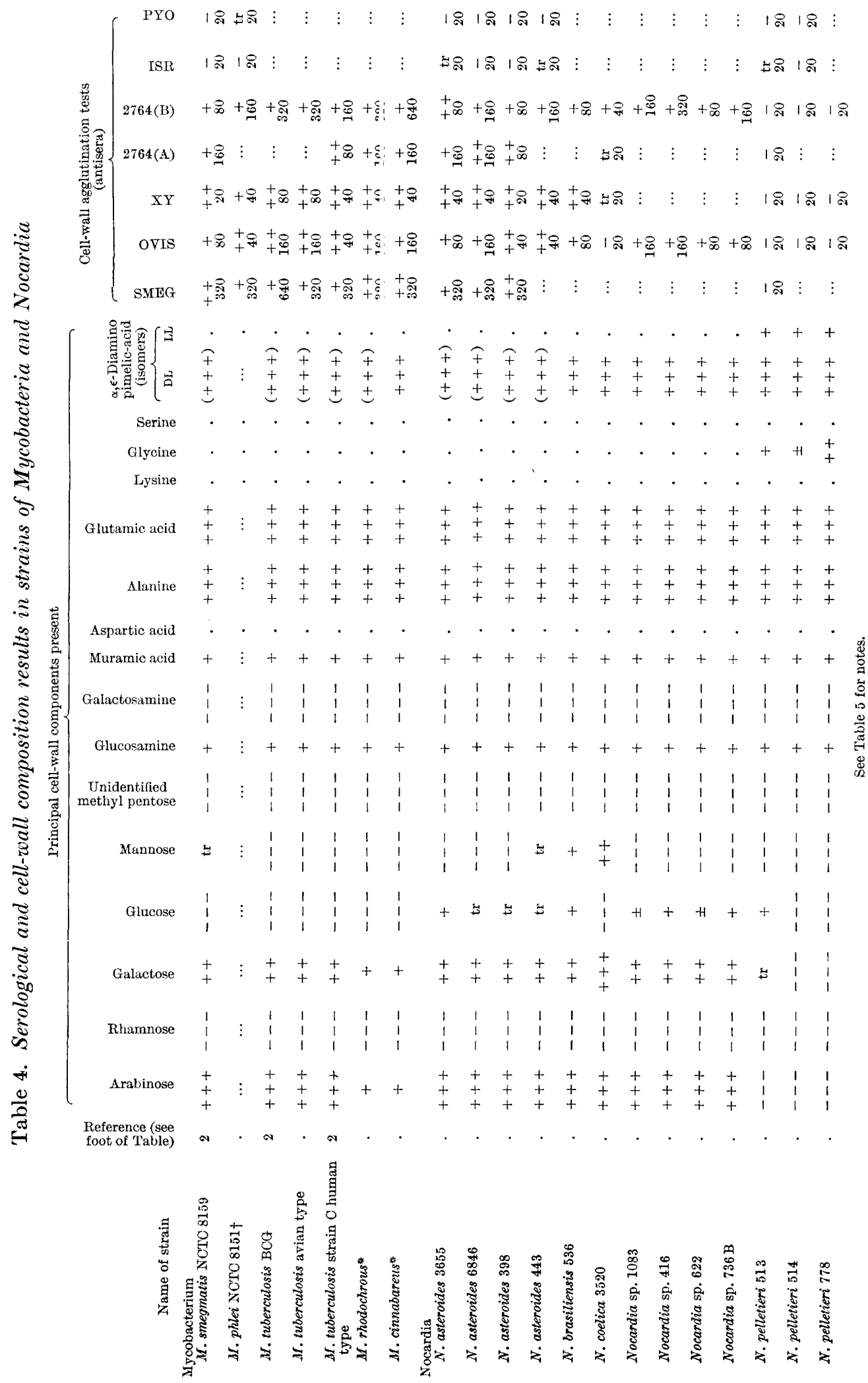




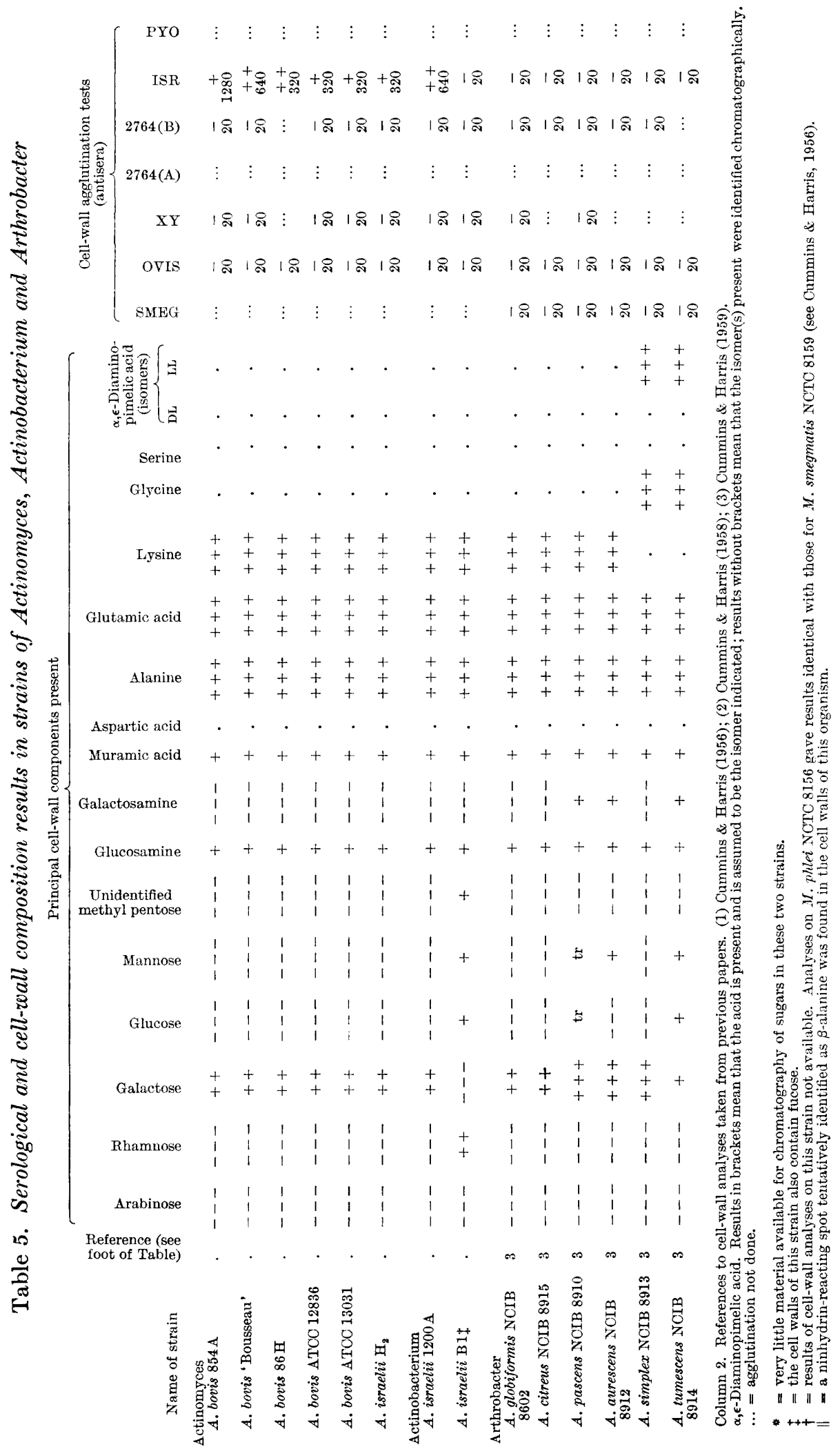


lococcus-micrococcus group (Cumnins \& Harris, 1956b). Of the other plant pathogenic corynebacteria, the strain of $C$. insidiosum appears to be related to Bacillus, and $C$. tritici NCPP 471 is extremoly unusual in that its cell walls seem to contain neither lysine nor diaminopimelic :ıcid, but hydrolysates gave a strong spot tentatively identified as $\beta$-alanine, in addition to alanine, glutamic acid and glycine. It was not possible to investigate this further because of lack of material, but the result requires confirmation, because up to now all Gram-positive organisms investigated have contained either lysine or diaminopimelic acid in their cell walls. The results with this strain of $C$. tritici are included here for comparison, and because its cell walls have also been examined serologically. The three strains of $C$. fascians are the only plant pathogens who se walls are characterized by the arabinose+ galactose pattern of major components, identical with that found in $C$. diphtheriae. As mentioned later, this relationsh ip of $C$. fascians to the type species of Corynebacterium is borne out by the serological results.

Other strains, shown in Table 5, are 8 microaerophilic actinomyces, and 6 arthrobacters. The results on the arthrobacter strains, included for comparative purposes, have been published previously (Cummins \& Harris, 1959b), and need no special comment. The results on the 8 actinomyces strains, however, have not previously been reported; all of them, except for strain $\mathrm{B} 1$, have a very constant pattern of cell-wall components, with galactose as the only sugar detected, and the amino acids, alanine, glutamic acid and lysine. This pattern was previously found to be characteristic of strains of actinomyces from human lesions, although it has been found occasionally in strains of bovine origin (Cummins \& Harris, 1959a). It has been suggested that such strains be called Actinomyces israelii rather than $A$. bovis to avoid the use of the specific epithet 'bovis' for what appears to be a more distinctively human parasite (Cummins \& Harris, 1958). Bovine strains (i.e. those most frequently isolated from bovine material) are characterized by an unusual combination of cell-wall sugars which includes rhamnose, fucose and another unidentified methylpentose. The strain called Actinobacterium israelii B 1 appears from its sugars to belong to the bovine group, although it lacks aspartic acid, which is generally present as a major cell-wall component in bovine strains (Cummins \& Harris, 1958, 1959a). Pine, Howell \& Watson (1960) recently reported a detailed morphological and physiological investigation of human and bovine strains of actinomyces. As a result of this they concluded that $A$. israelii and $A$. bovis could be separated quite clearly on the bisis of cultural characteristics and fermentation tests.

Agglutination tests. Although there are gaps in the Tables, all the cell-wall samples included were tested against at least two sera, and in most cases four or more. In addition, all the samples were tested at dilution 1/20 against a Shigella shigae serum as a control, and all were negative. None of the sera used had a particularly high titre, but SMEG and $27(4(\mathrm{~B})$ gave titres of 1/320 against homologous cell walls (Mycobacterium smegmati: NCTC 8159 and Corynebacterium diphtheriae 2764, respectively). Reactions with the older sera (OVIS, XY, 2764(A) and PYO) were at rather lower titres, but it is clifficult to say how much of this was due to the long storage ( 6 years at $4^{\circ}$ ), since only one of them had been tested previously. This serum 2764 (A) had a titre of 1/320 against homologous cell walls when tested in 1954, and 6 years later the titre was $1 / 160$ (see Table 3). The serum ISR, prepared 
against $A$. israclii, could not be tested against cell-wall suspensions from the homologous organism, as cultures of this had unfortunately been lost by the time that the animal was bled. However, this serum reacted in such a clear-cut manner with cell walls from other actinomyces of the same type, that it seems justifiable to include the results.

With the seven sera used, the positive cell-wall agglutinations appeared to fall into three groups.

Group 1: mycobacteria, nocardias and corynebacteria whose cell walls reacted with sera SMEG, OVIS, XY, 2764 (A) and 2764(B). Most of these cell-wall suspensions gave strong agglutination at 1/40 at least, and often at much higher dilutions, with all five sera. It will be seen, however (Table 3), that some corynebacteria, and a smaller number of strains of nocardia react negatively (i.e. no reaction at $1 / 20$ ), or give anomalous reactions with these five sera. Four of the corynebacteria which did not react are the four strains of Corynebacterium pyogenes (Group 3, below). The other strains of corynebacteria that gave negative results were the plant pathogens other than C. fascians, and C. simplex A'TCC 8373. The cell walls of $C$. hofmannii gave anomalous results, being apparently negative with sera OVIS and XY, weakly positive with $2764(\mathrm{~B})$ and doubtful ( \pm at $1 / 20$ ) with ISR and PYO. The nocardias which gave negative or anomalous results were the 3 strains of Nocardia pelletieri (all negative throughout at $1 / 20$ ) and the strain of $N$. coelica which was negative with serum OVIS and weakly positive ( + at $1 / 40$ ) with $2764(\mathrm{~B})$.

Group 2: strains of actinomyces whose cell walls reacted with ISR serum at titres of $1 / 320$ or more but which were negative with all other sera tested. The only strain of actinomyces which was negative with this ISR serum was Actinobacterium israelii B 1 .

Group 3: the four strains of Corynebacterium pyogenes whose cell walls agglutinated with serum PYO, but not with any of the other sera against which they were tested.

In a certain number of cases complement-fixation tests were also done with these seven sera, using celi-wall suspension as antigens. The technique of complementfixation was that used as a routine in the London Hospital Bacteriology Department for the titration of virus antigens (Bedson, Barwell, King \& Bishop, 1949). A satisfactory antigen concentration was $0.2 \mathrm{mg}$. cell walls $/ \mathrm{ml}$. (this was diluted a further $1 / 4$ in setting up the test) and it was found better to allow fixation to occur overnight at $4^{\circ}$. Broadly speaking, the results paralleled those of agglutination but several of the cell-wall suspensions were somewhat anticomplementary, and there were rather more cross-reactions. For these reasons the use of the method was not pursued.

Absorption tests. A rather limited range of absorption tests was done as a check on the results of direct agglutination. The serum used in most cases was SMEG, which was absorbed with a variety of cell-wall preparations and then tested against cell-wall suspensions from five different organisms which normally gave positive agglutination reactions with this serum. A typical series of results is shown in Table 6. In all cases except one the cell-wall preparation used to absorb appeared to have removed all antibody to the homologous organism (Mycobacterium smegmatis NCTC 8159) and, as would be expected, the reactions to the other four cellwall suspensions were also negative in these cases. However, it is obvious that after absorption with the cell walls of Nocardia pelletieri 513, the titre of the serum to 
the tests suspensions was virtually unaltered, except in the case of $N$. asteroides 398 where there was a decrease in titre from $1 / 320$ to $1 / 160$ ( 1 tube). Since the cell-wall suspensions of $N$. pelletier; 513 did not agglutinate with any of the sera used, the results of these absorytion tests appear to confirm those of direct agglutination.

'Table 6. Absorption tests with My'cobacterium smegmatis serum (serum SMEG)

\begin{tabular}{|c|c|c|c|c|c|c|c|}
\hline $\begin{array}{l}\text { Serum SMEG } \\
\text { absorbed with }\end{array}$ & $\begin{array}{l}\text { Absorbed serur a tested } \\
\text { against cell walls of }\end{array}$ & 40 & 80 & 160 & 320 & 640 & 1280 \\
\hline $\begin{array}{l}\text { Cell walls from } \\
\text { Nocardia asteroides } \\
6846\end{array}$ & $\begin{array}{l}\text { M. smegmati } 8159 \\
\text { M. phlei } 815 \text { ? } \\
\text { C. fascians } 1: 6 \\
\text { N. asteroides } 398 \\
\text { C. diphtherial } 2764\end{array}$ & $\begin{array}{l}- \\
- \\
- \\
-\end{array}$ & $\begin{array}{l}- \\
- \\
- \\
-\end{array}$ & $\begin{array}{l}- \\
- \\
- \\
-\end{array}$ & $\begin{array}{l}- \\
- \\
- \\
-\end{array}$ & $\begin{array}{l}- \\
- \\
- \\
-\end{array}$ & $\begin{array}{l}- \\
- \\
- \\
-\end{array}$ \\
\hline $\begin{array}{l}\text { Cell walls from } \\
N . \text { pelletieri } 513\end{array}$ & $\begin{array}{l}\text { M. smegmati: } 8159 \\
\text { M. phlei } 815 \\
\text { C. fascians } 1: 6 \\
\text { N. asteroides } 398 \\
\text { C. diphtherial } 2764\end{array}$ & $\begin{array}{l}++ \\
++ \\
++ \\
++ \\
++\end{array}$ & $\begin{array}{l}++ \\
++ \\
++ \\
+ \\
++\end{array}$ & $\begin{array}{r}+ \\
++ \\
++ \\
+ \\
++\end{array}$ & $\begin{array}{l}+ \\
+ \\
+ \\
- \\
+\end{array}$ & $\begin{array}{l}- \\
- \\
- \\
-\end{array}$ & $\begin{array}{l}- \\
- \\
- \\
- \\
-\end{array}$ \\
\hline $\begin{array}{l}\text { Cell walls from } \\
\text { Mycobacterium } \\
\text { tuberculosis BCG }\end{array}$ & $\begin{array}{l}\text { M. smegmati } 8159 \\
\text { M. phlei } 815 \\
\text { C. fascians } 1: 6 \\
\text { N. asteroides } 398 \\
\text { C. diphtheria } 2764\end{array}$ & $\begin{array}{l}- \\
- \\
- \\
- \\
-\end{array}$ & $\begin{array}{l}- \\
- \\
- \\
- \\
-\end{array}$ & $\begin{array}{l}- \\
- \\
- \\
-\end{array}$ & $\begin{array}{l}- \\
- \\
- \\
- \\
-\end{array}$ & $\begin{array}{l}- \\
- \\
- \\
- \\
-\end{array}$ & $\begin{array}{l}- \\
- \\
- \\
-\end{array}$ \\
\hline $\begin{array}{l}\text { Cell walls from } \\
M \text {. tuberculosis, avian } \\
\text { type }\end{array}$ & $\begin{array}{l}\text { M. smegmati: } 8159 \\
\text { M. phlei } 815 \\
\text { C. fascians } 116 \\
\text { N. asteroides } 398 \\
\text { C. diphtheriac } 2764\end{array}$ & $\begin{array}{l}- \\
- \\
- \\
-\end{array}$ & $\begin{array}{l}- \\
- \\
- \\
-\end{array}$ & $\begin{array}{l}- \\
- \\
- \\
-\end{array}$ & $\begin{array}{l}- \\
- \\
- \\
- \\
-\end{array}$ & $\begin{array}{l}- \\
- \\
- \\
- \\
-\end{array}$ & $\begin{array}{l}- \\
- \\
- \\
-\end{array}$ \\
\hline $\begin{array}{l}\text { Cell walls from } \\
N \text {. asteroides } 3655\end{array}$ & $\begin{array}{l}\text { M. smegmati: } 8159 \\
\text { M. phlei } 815 \\
\text { C. fascians } 14,6 \\
\text { N. asteroides } 398 \\
\text { C. diphtheriat } 2764\end{array}$ & $\begin{array}{l}- \\
- \\
- \\
- \\
-\end{array}$ & $\begin{array}{l}- \\
- \\
- \\
- \\
-\end{array}$ & $\begin{array}{l}- \\
- \\
- \\
-\end{array}$ & $\begin{array}{l}- \\
- \\
- \\
- \\
-\end{array}$ & $\begin{array}{l}- \\
- \\
- \\
- \\
-\end{array}$ & $\begin{array}{l}- \\
- \\
- \\
-\end{array}$ \\
\hline Unabsorbed serum & $\begin{array}{l}\text { M. smegmatis } 8159 \\
\text { M. phlei } 815 \text {. } \\
\text { C. fascians } 166 \\
\text { N. asteroides } 398 \\
\text { C. diphtheriat } 2764\end{array}$ & $\begin{array}{l}++ \\
++ \\
++ \\
++ \\
++\end{array}$ & $\begin{array}{l}++ \\
++ \\
++ \\
++ \\
++\end{array}$ & $\begin{array}{l}++ \\
++ \\
++ \\
++ \\
++\end{array}$ & $\begin{array}{r}++ \\
+ \\
++ \\
++ \\
+\end{array}$ & $\begin{array}{l}\operatorname{tr} \\
\operatorname{tr} \\
+ \\
- \\
-\end{array}$ & $\begin{array}{l}- \\
- \\
- \\
-\end{array}$ \\
\hline
\end{tabular}

A few absorption tests were don: with other sera and cell-wall suspensions, with similar results. For example, absorption of serum 2764(B) (produced against Corynebacterium diphtheriae $2764 \mathrm{t}$ pe mitis) with cell walls from another strain of C. diphtheriae removed all antibodies for the homologous organism. On the other hand, when this serum was absorbed with cell walls from Actinomyces bovis 854 A or Nocardia pelletieri 514, the tit:e against the homologous cell-wall suspension was not reduced. In another serits of tests, serum OVIS was absorbed with cell walls from nocardia strains $416,1083,736 \mathrm{~B}, N$. coelica 3520, and Mycobacterium tuberculosis, avian type, and antibody to the homologous cell walls was removed in each case. This result is of pasticular interest in the case of $N$. coelica 3520 , which was negative in the direct agglutination test with this serum but which, on grounds of cell-wall composition, appears to belong to the same group as the strains of $N$. asteroides and $N$. brai iliensis. 


\section{DISCUSSION}

It is doubtful whether agglutination tests with cell-wall suspensions prepared by the method described in this paper can be compared with agglutination tests using suspensions of intact bacteria. In the case of Corynebacterium diphtheriae, for example, a large number of distinct serological types is found when suspensions of intact organisms are used (see Hewitt, 1947). These type-specific antigens are almost certainly protein, since the antigen responsible for the agglutination of suspensions of a strain of $C$. diphtheriae type mitis (strain 2764 of the present paper) is relatively heat labile and is destroyed by pepsin though not by trypsin (Cummins, 1954). The protein antigen responsible for agglutination of intact organisms of this strain (2764) could still be demonstrated in the cell-wall fractions from disintegrated organisms, both by using such fractions to immunize rabbits and by absorption tests, but the cell-wall suspensions agglutinated only in the presence of antibody to the polysaccharide antigen which was shared by all the strains of $C$. diphtheriae and $C$. ovis tested (and which is assumed to be the widely distributed cell-wall antigen of the present investigation). It seems that in the cell-wall fragments so many new surfaces are exposed that this antigen becomes dominant.

With mycobacteria and nocardias, agglutination of intact organisms presents technical difficulties because of the great tendency to spontaneous clumping. Schneidau \& Schaffer (1960) investigated over 50 strains of mycobacteria and nocardias by slide agglutination, using suspensions ground with celite, and homogenized in a Waring blendor in buffered saline containing $0.1 \%$ sodium taurocholate. They found considerable cross-reaction between strains of Nocardia asteroides, $N$. brasiliensis, $N$. corallina, and $N$. opaca, and rather less between sera to these strains, and suspensions of mycobacteria. A somewhat different approach was reported by Kirsh \& Shepard who examined cell-wall fractions from a number of strains of mycobacteria using fluorescent antibody staining. They found a considerable amount of interspecies cross-reaction with unabsorbed sera, although absorption tests suggested that species-specific antigens were also present (Kirsh \& Shepard, 1961; Shepard \& Kirsh, 1961). These results broadly show the same pattern of cross-reactions as has been found in the present work, wherever strains of the same kind have been examined. For example, both by direct agglutination and by absorption (and also in terms of cell-wall composition), strains of Nocardia asteroides are distinct from those of $N$. pelletieri. It seems possible that the rather extensive grinding procedure used by Schneidau \& Schaffer (1960) produced at least some degree of cell destruction so that their antigens contained cell-wall fragments together with intact organisms. Ludwig \& Hutchinson (1949) used sonically disintegrated suspensions of nocardias and streptomyces (which presumably consisted largely of cell-wall fragments) in agglutination tests, and found little cross-reaction between members of these two groups, although their antisera gave agglutination at high titre (i.e. up to 1/2560) against the homologous suspensions. They did not test their antisera against cell-wall preparations from mycobacteria or corynebacteria. Kotani et al. $(1959,1960)$ have also recently reported on the chemical and serological properties of cell-wall fractions from BCG. The chemical results agree with those reported here, in that arabinose and galactose, hexosamine, alanine, glutamic acid and diaminopimelic acid were found to be the principal components. 
These workers found that the cell-wall fraction fixed complement with rabbit antisera; the reactions of the BCG cell walls with sera to other mycobacteria was not tested.

The chemical nature of the antigenic determinants involved has not been specifically investigated in the present work. However, previous results (Cummins, 1954) showed that the antigen responsible for cross-agglutination between cell-wall suspensions of strains of Corynebacterium diphtheriae and C. ovis was almost certainly polysaccharide since it withstood heating at $100^{\circ}$ for $4 \mathrm{hr}$., but was quite rapidly destroyed by periodate oxidation. Since three of the sera prepared at that time (OVIS, XY and $2764 \mathrm{~A}$ ) were used in the present series of tests and showed the same pattern of reactions as did sera prepared more recently (SMEG and $2764 \mathrm{~B}$ ) it seems reasonable to suppose that the antigen in corynebacteria, mycobacteria and nocardias with which all five sera react is polysaccharide in nature and is probably identical with the antigen described in the earlier paper (Cummins, 1954). It is unlikely to be protein, since the cell-wall suspensions were routinely treated with trypsin and pepsin. If the antigen is a polysaccharide, it is tempting to suppose that its specificity is connected with araoinose or some small unit containing it, since this sugar appears to be confined to the group of organisms concerned.

Polysaccharides containing arabinose have in the past been extracted from human, bovine and avian tubercle oacilli (Heidelberger \& Menzel, 1937; Menzel \& Heidelberger, 1939; Karjala \& Heidelberger, 1941 ; see also Stacey, 1955), from other mycobacteria (see Tennent \& Watson, 1942) and from tuberculin (Siebert, Pederson \& Tiselius, 1938). 'These polysaccharides precipitated at high dilution with antisera, and fractions from human, bovine, avian and other strains cross-reacted. Since it is now apparent that arabinose and galactose are major sugar components of the cell wall in mycobacteria, it seems possible that such polysaccharides come ultimately from this source, but their relatior to the cell-wall antigen here described has not yet been investigated.

It must be noted that some of the results of agglutination tests recorded here are at variance with those reported previously (Cummins, 1954). In the earlier investigations it was noticed that cell-wall suspensions from two strains of Corynebacterium hofmannii, two of C. xerc sis and one of C. renale either did not agglutinate with an antiserum to $C$. diphtheria' or did so at much lower titres than those given by the homologous cell-wall suspension. Moreover, in absorption tests done at that time, these strains did not appear to be able to remove antibodies for this serum to any significant extent, and it was therefore suggested that they did not contain the group antigen shared by the strans of $C$. diphtheriae and $C$. ovis used. In the present series of tests the cell-wall suspensions from $C$. hofmannii L.H. were again found to agghutinate only to low the with serum against $C$. diphtheriae 2764 , but suspensions from C. renale NCTC 7448 and C. xerosis NCTC 9755 agglutinated to titres which did not differ significa atly from those given by the homologous strain. These discrepancies may be due to the fact that in the present work the cell-wall suspensions have been extracted with alkaline ethanol or that different strains of C. renale and C.xerosis were used, or more probably because of the longer period of incubation ( $2 \mathrm{hr}$. instead of $\left.1 \mathrm{hr} . \mathrm{a} ; 56^{\circ}\right)$ and to the fact that the tests were allowed to stand at room temperature for $18-24 \mathrm{hr}$. before being read. The results of agglutination tests with $C$. hofmannii are still rather unexpected, in view of 
its cell-wall composition, and there is no satisfactory explanation for this discrepancy.

From the taxonomic point of view, the results described here seem to reinforce those of a previous paper (Cummins \& Harris, 1958) where because of their similarity in cell-wall composition it was suggested that corynebacteria, mycobacteria and nocardias were closely related, and that strains of these three groups should not be artificially separated by placing Mycobacterium and Nocardia in the order Actinomycetales, while Corynebacterium was included in the Eubacteriales. The present work appears to confirm this view, both on grounds of cell-wall composition and of serological specificity. The results also show that the genus Corynebacterium contains a number of species which, in terms of cell-wall composition and serology, are very different from the type-species, and it seems possible that some of these may need to be reclassified. The grounds on which it has been suggested that Corynebacterium pyogenes much more closely resembles the streptococci than the corynebacteria have already been published (Cummins \& Harris, $1956 a$; Barksdale, Li, Cummins \& Harris, 1957). It seems very likely that the cell-wall agglutination results for the four strains of $C$. pyogenes, given in Table 3, are due to the same antigen as was previously detected in formamide extracts. The strains of $C$. tritici, C. betae, C. poinsettiae, $C$. insidiosum and $C$. flaccumfaciens did not react with any of the antisera available, and their antigenic relationships to each other, if any, remain unknown. However, these organisms seem to be quite clearly different from those corynebacteria which have the arabinose + galactose cell-wall pattern and from the four strains of $C$. pyogenes.

It was noted previously (Cummins \& Harris, 1959b) that some strains of Arthrobacter have a pattern of cell-wall components similar to that of strains of microaerophilic actinomyces of the 'israelii' type (i.e. those mostly associated with human actinomycosis). However, as can be seen from Table 5, the cell-wall suspensions of these arthrobacter strains do not react with the anti-israelii serum ISR. This suggests the need for caution in interpreting qualitative cell-wall analyses too directly in terms of taxonomic relationships unless they are reinforced by serological and other tests.

Most of this work was done in the Bacteriology Department, London Hospital Medical College, and it was finished and the manuscript prepared while the author was working as Visiting Investigator in the Department of Microbiology, Northwestern University Medical School, Chicago, Illinois, U.S.A. I wish to thank Professor C. F. Barwell of the London Hospital, and Dr G. P. Youmans and Dr H. D. Slade of Northwestern University for their help and advice.

I am very grateful to my colleague Professor H. Harris (Department of Biochemistry, King's College, London), for considerable help with much of the chromatography, and also to those who provided strains for examination, in particular Dr Ruth Gordon (Rutgers University, New Jersey, U.S.A.). 


\section{REFERENCES}

Barksdale, W. L., Li, K., Cummins, (.. S. \& Harris, H. (1957). The mutation of Corynebacterium pyogenes to Corynebacteriun haemolyticum. J. gen. Microbiol. 16, 749.

Bedson, S. P., Barweli, C. F., King, E. J. \& Bishop, L. W. J. (1949). The laboratory diagnosis of lymphogranuloma venei eum. J. clin. Path. 2, 241.

Cummins, C. S. (1954). Some observations on the nature of the antigens in the cell wall of Corynebacterium diphtheriae. Brit. J, exp. Path. 35, 166.

Cummins, C. S. \& Harris, H. (1956a). The chemical composition of the cell wall in some gram-positive bacteria and its possible value as a taxonomic character. J. gen. Microbiol. 14, 583 .

Cummins, C. S. \& Harris, H. (1956b). The relationship between certain members of the staphylococcus-micrococcus group as shown by their cell wall composition. Int. Bull. Bact. Nomencl. 6, 111.

Cummins, C. S. \& Harris, H. (1958). Studies on the cell wall composition and taxonomy of actinomycetales and related grou])s. J. gen. Microbiol. 18, 173.

Cummins, C. S. \& Harkis, H. (1959a). Cell wall composition in strains of Actinomyces isolated from human and bovine lesions. J. gen. Microbiol. 21, ii.

Cummins, C. S. \& Harris, H. (1959b). Taxonomic position of Arthrobacter. Nature, Lond. 184,831 .

Heidelberger, M. \& Menzei, A. E. O. (1937). Specific and non-specific cell polysaccharides of a human strain of tuberc le bacillus, H37. J. biol. Chem. 118, 79.

Hewite, L. F. (1947). Serological typing of C. diphtheriae. Brit. J. exp. Path. 28, 338.

Karjala, S. A. \& Heidelberger, M. (941). Specific and non-specific cell polysaccharides of an avian strain of tubercle bacillus. J. biol. Chem. 137, 189.

Kirsh, D. \& Shepand, C. (1961). Se ological relationships among mycobacteria. Fed. Proc. 20, 16.

Kotani, S., Kitauna, T., Hmano, ']'. \& 'Tanaka, A. (1959). Isolation and chemical composition of the cell walls of BCG. Biken's J. 2, 129.

Komani, S., Kitaura, T., Higashigawa, M., Kato, K., Mori, Y., Matsubara, T. \& Tsujimoto, T. (1960). Studies on the immunological properties of the cell wall, particle and soluble-fractions of sonicated BCG cells. Biken's J. 3, 159.

Lunwig, L. H. \& Hutchinson, W. G. (1949). A serological study of selected species of actinomyces. J. Bact. 58, 89.

Menzel, A. E. O. \& Heidelberger, M. (1939). Specific and non-specific cell polysaccharides of a bovine strain of tubercle bacillus. J. biol. Chem. 127, 221.

Mickle, H. (1948). A tissue disintegrator. J. roy. micr. Soc. 68, 10.

Pine, L., Howell, A. \& Watson, Sar.u J. (1960). Studies of the morphological, physiological and biochemical characters o Actinomyces bovis. J. gen. Microbiol. 23, 403.

Schneidau, J. D. \& Schaffer, M. F. (1960). Studies on Nocardia and other Actinomycetales. II. Antigenic relationships shown by slide agglutination tests. Amer. J. resp. Dis. 82, 64 .

Shepard, C. C. \& Kirsi, D. (1961). Disruption of mycobacteria and their stainability by fluorescent antibody. Fed. Proc. 20, 16.

Siebert, F. B., Pederson, K. O. \& 'Tis zlius, A. (1938). Molecular weight, electrochemical and biological properties of tuberce lin protein and polysaccharide molecules. $J$. exp. Med. 68, 413.

Slavin, D. (1950). Production of antisera in rabbits using calcium alginate as an antigen depot. Nature, Lond. 165, 115.

Stacey, M. L. (1955). Polysaccharides of the tubercle bacillus. In Ciba Foundation Symposium on Experimental Tuberculosis. London: Churchill.

'Tennent, D. M. \& Watson, D. W. (1942). Molecular kinetic analyses and serological specificities of polysaccharides isola sed from filtrates of the human tubercle bacillus and related species. J. Immunol. 45179. 